\title{
DETEKSI CORONAVIRUS DISEASE PADA $X$-RAY DAN CT-SCAN PARU MENGGUNAKAN CONVOLUTIONAL NEURAL NETWORK
}

\author{
Muhammad Ridho Fauzi ${ }^{1)}$, Puspa Eosina ${ }^{2 *}$, Dewi Primasari ${ }^{3 *}$ \\ ${ }^{1}$ Fakultas Teknik \& Sains, Universitas Ibn Khaldun Bogor \\ email: ralhafizhi@gmail.com \\ ${ }^{2}$ Fakultas Teknik \& Sains, Universitas Ibn Khaldun Bogor \\ email: puspa.eosina@ft.uika-bogor.ac.id \\ ${ }^{3}$ Fakultas Teknik \& Sains, Universitas Ibn Khaldun Bogor \\ email: dewiprimasari2@yahoo.com
}

\begin{abstract}
In early 2020, countries in the world were shocked by the outbreak of a new virus, namely SARS-CoV2 and the disease was named Coronavirus 2019 (Covid-19). It is known that the virus originated in Wuhan, China and was discovered at the end of December 2019. Based on data on July 18, 2020, there are more than 180 countries that have contracted Covid-19 with a total of 13,824,739 confirmed cases since December 31, 2019. Based on data on positive cases of Covid-19 above, the average patient has several clinical symptoms, one of which is having difficulty breathing due to a large pneumonia infiltrate in the lungs. Therefore, it is necessary to implement an automatic pulmonary diagnosis system as an alternative to prevent the increasingly widespread spread of Covid-19. Covid19 can be detected in the lungs through digital image processing of chest X-ray using the Convolutional Neural Network (CNN) algorithm. CNN is a Deep Learning method that functions to identify digital images. In this study, three different scenarios were used. This scenario aims to find the best model using hyperparameter tunnning. The results of ROC analysis and confusion matrix show that in scenarios I, II and III get 94\%, 95\% and 93\% accuracy.
\end{abstract}

Keywords: Chest X-Ray, Convolutional Neural Network (CNN), Covid-19, Deep Learning.

\section{PENDAHULUAN}

Pada awal tahun 2020, negara-negara di dunia digemparkan dengan mewabahnya virus baru yaitu SARS-CoV-2. Diketahui, virus tersebut berasal dari Wuhan, Tiongkok dan ditemukan pada akhir Desember tahun 2019. Pada awalnya data epidemiologi menunjukkan sekitar $66 \%$ pasien berkaitan dengan pasar seafood yang berada di Wuhan, Tiongkok (Huang, et. al., 2020). Dengan data tersebut, maka dilakukan pengujian sampel isolat dari pasien yang menunjukkan hasil bahwa adanya infeksi coronavirus jenis baru tersebut.

World Health Organization memberi nama virus jenis baru tersebut Severe Acute Respiratory Syndrome Coronavirus-2 (SARS$\mathrm{CoV}-2)$ dan penyakitnya diberi nama Coronavirus disease 2019 atau Covid-19 (WHO, 2020). Pada awalnya virus ini belum bisa ditentukan apakah transmisi atau penyebarannya dapat melalui antara manusia satu dengan yang lainnya. Namun, seiiring dengan berjalannya waktu, jumlah kasus tersebut mengalami peningkatan dan selain itu, terdapat kasus 15 petugas medis terfinfeksi oleh salah satu pasiennya (Channel News Asia, 2020). Maka pada akhirnya, dapat dikonfirmasi bahwa transmisi atau penyebarannya ini dapat menular dari manusia ke manusia lainnya (Relman, 2020). Sampai saat ini virus tersebut dengan cepat menyebar ke negara-negara di dunia dan penelitian hal ini pun masih berlanjut hingga kini.

Berdasarkan data pada tanggal 18 Juli 2020 negara yang terdampak oleh Covid-19 berjumlah lebih dari 180 negara termasuk Indonesia dengan total kasus terkonfirmasi sejak tanggal 31 Desember 2019 sebanyak 13.824.739 penderita dan total kasus kematian sebanyak 591.666 kasus kematian (WHO, 2020). Sedangkan di Indonesia, sampai saat ini kasus terkonfirmasi sebanyak 84.882 penderita dan total kasus kematian sebanyak 4.016 kasus kematian (Kemenkes, 2020).

Berdasarkan data kasus positif Covid-19 di atas, rata-rata penderita memiliki beberapa tanda-tanda dan gejala klinis. Gejala tersebut sebagian besar adalah demam, dengan beberapa kasus mengalami kesulitan bernapas, dan jika dilihat dari hasil rontgen 
menggunakan CT-Scan (pemindaian Computed Tomography) dan X-ray menunjukkan infiltrat Pneumonia luas di kedua paru (WHO, 2020). CT-Scan pada paruparu adalah salah satu metode yang digunakan untuk melihat dan mendiagnosis Pneumonia. Alat tersebut bekerja secara otomatis menggunakan sinar-X berbasis Artificial Intelligence untuk mendeteksi, melakukan pemantauan Pneumonia pada paru pasien (Gozes, 2020).

Data X-ray dan CT-Scan paru-paru pernah diteliti oleh Asmaa Abbas dkk, mereka melakukan penelitian menggunakan $\mathrm{CNN}$ dengan metode transfer learning dalam mendeteksi kasus Covid-19 pada dataset gambar X-ray paru (Asmaa Abbas, 2020). Penelitian yang lain dilakukan oleh Ali Narin dkk, mereka membangun sebuah model prediksi dengan metode transfer learning dengan menggunakan tiga arsitektur model CNN, yaitu ResNet50, InceptionV3 dan InceptionResNetV2 dalam mendeteksi pasien yang terinfeksi Pneumonia, menggunakan radiografi sinar-X dada (Ali Narin, 2020). Penelitian yang lain yang dilakukan oleh Aswindo Putra dalam mengklasifikasikan data ekspresi gen kanker dengan menggunakan algoritma Stacked Sparse Autoencoder (Aswindo Putra, 2018).

Berdasarkan uraian tersebut, maka teknologi Artificial Intelligence khususnya pada Deep Learning akan mempengaruhi pada salah satu bidang, yaitu kedokteran. Deep Learning merupakan cabang dari Artificial Intelligence berbasis Jaringan Saraf Tiruan (JST). Deep Learning telah menunjukkan eksistensinya di berbagai bidang yaitu identifikasi bahasa, pengelanan gambar, pemahaman bahasa dan pengambilan keputusan. (Sun, dkk, 2017) menyebutkan kelebihan dari metode tersebut adalah dapat menangani data mentah yang kompleks secara otomatis dan mempelajari fitur-fitur yang berguna serta abstrak. Oleh karena itu, Deep Learning sangat cocok untuk memecahkan masalah pada bidang ini (kedokteran) khususnya berkaitan dengan image recognition pada $C T$-Scan paru-paru. Pada bidang kedokteran, hasil CT-Scan atau rontgen berbasis model Deep Learning pada paru-paru memiliki peran yang sangat penting dalam mengidentifikasi pasien tersebut terinfeksi oleh virus atau tidak.
Pada penelitian ini dilakukan analisis terhadap data X-ray dan CT-Scan paru menggunakan metode Deep Learning. Maka tujuan penelitian ini adalah membangun model deteksi Covid-19 pada CT-Scan dan Xray paru-paru menggunakan salah satu algoritma Deep Learning, yaitu Convolutional Neural Network (CNN). Pada penelitian ini, dilakukan tiga skenario $\mathrm{CNN}$ yang berbeda. Skenario tersebut bertujuan untuk mencari model terbaik dengan cara tunning hyperparameter.

Algoritma CNN digunakan untuk mendapatkan informasi representatif yang baru hasil dari perkalian gambar dengan filter (konvolusi) yang digunakan pada lapisan convolutional dan mendapatkan fitur ekstraksi. Setelah itu hasil ekstrasi tersebut dimasukan ke dalam layer softmax untuk proses klasifikasi atau prediksi. Penelitian ini diharapkan dapat berkontribusi pada permasalahan yang sedang dihadapi saat ini, khususnya pada bidang kesehatan dan penelitian pada bidang kecerdasan buatan.

\section{METODE PENELITIAN}

Berikut adalah prosedur penelitian yang digunakan dalam penelitian ini dapat dilihat pada Gambar 1. 


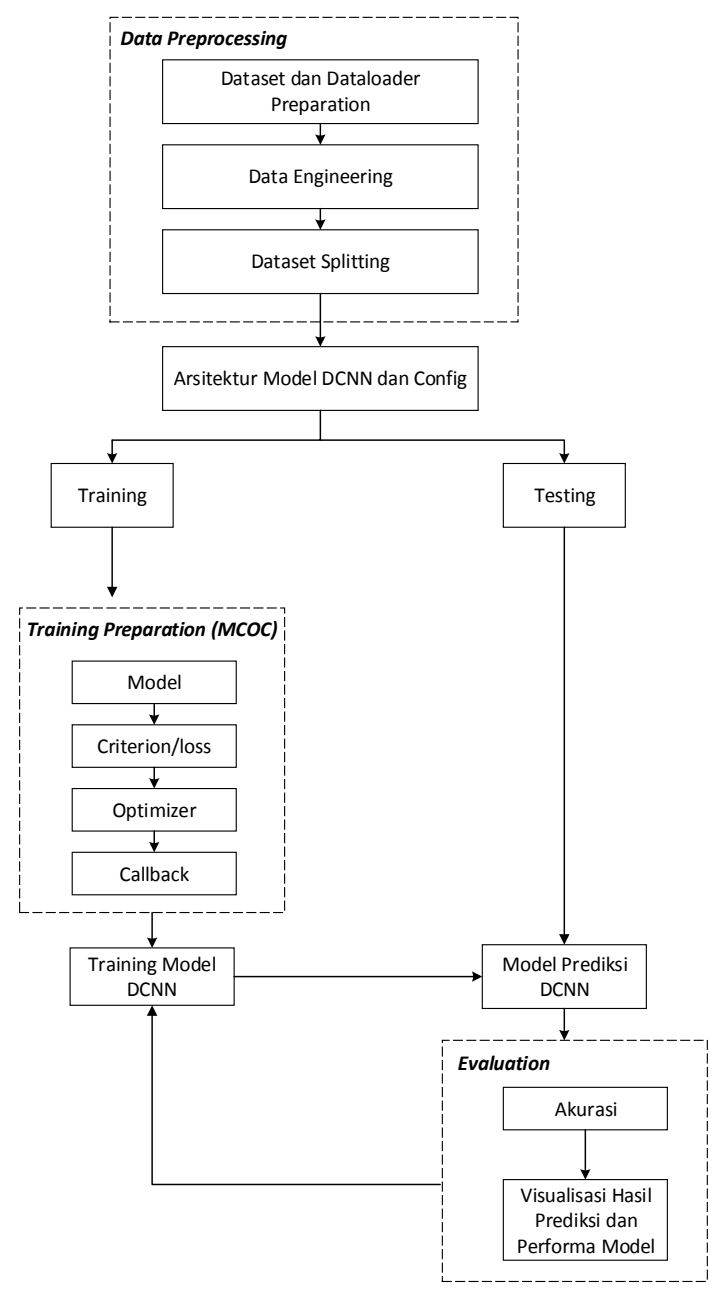

Gambar 1. Bagan Prosedur Penelitian

\section{A. Data Preprocessing}

Data Preprocessing ini dimaksudkan untuk mempersiapkan data yang akan digunakan pada penelitian ini agar data yang diperoleh, dapat diproses dengan baik oleh model yang akan dibuat, yaitu model CNN. Beberapa tahapan yang akan dilakukan dalam data preprocessing adalah sebagai berikut:

\section{Dataset dan Dataloader}

Dataset citra X-ray dan CT-Scan paru-paru yang digunakan terdiri dari 5074 citra X-ray dan CT-Scan paruparu yang terbagi ke dalam 3 kelas yaitu Covid-19, normal, dan Pneumonia. Masing-masing kelas memiliki citra digital berformat . ${ }^{J} J P G$ atau . ${ }^{P} P G$ dengan resolusi yang beragam. Untuk mengatasi resolusi citra menjadi satu ukuran yang sama, maka tahap selanjutnya adalah melakukan transformasi citra menjadi ukuran yang sama, merubah warna menjadi grayscale dan mentransformasikan citra ke dalam bentuk tensor. Dalam hal ini menggunakan teknik data engineering yang akan dibahas pada tahap selanjutnya. Hal tersebut dilakukan agar data atau citra yang digunakan pada saat pembuatan model memiliki ukuran yang sama.

\section{Data Engineering}

Pada tahap ini dilakukan teknik data engineering. Data Enginering merupakan sebuah teknik untuk membuat arsitektur manajemen data atau menyiapkan infrastruktur data yang akan digunakan untuk tahap selanjutnya yaitu, proses training atau pembuatan model prediksi. Dalam hal ini yang dapat dilakukan adalah data augmentation. Data augmentation merupakan sebuah teknik untuk memanipulasi sebuah citra atau image tanpa menghilangkan makna atau inti dari citra tersebut. Data augmentation yang dapat dilakukan antara lain (dapat dilihat pada Gambar 2) :

a. Transformasi warna atau channel, pada citra X-Ray dan $C T$-Scan tersebut mempunyai lapisan channel satu, yang artinya citra tersebut mempunyai satu warna yaitu grayscale. Dalam hal ini agar semua citra X-Ray dan CT-Scan tersebut menjadi satu warna maka dilakukan transformasi warna atau channel.

b. Transformasi Random Rotation, hal ini dilakukan untuk mengatasi data yang sangat sedikit dan mengurangi overfitting.

c. Transformasi Random Resize Crop, hal ini dilakukan untuk mengatasi citra yang ukurannya berbeda-beda atau beragam. Sehingga dilakukan cropping pada citra tersebut menjadi $224 \times 224$ pixel.

d. Transformasi Tensor, dalam hal ini citra tersebut akan diubah ke dalam bentuk tensor agar dapat 
dibaca pada saat proses pembuatan model.

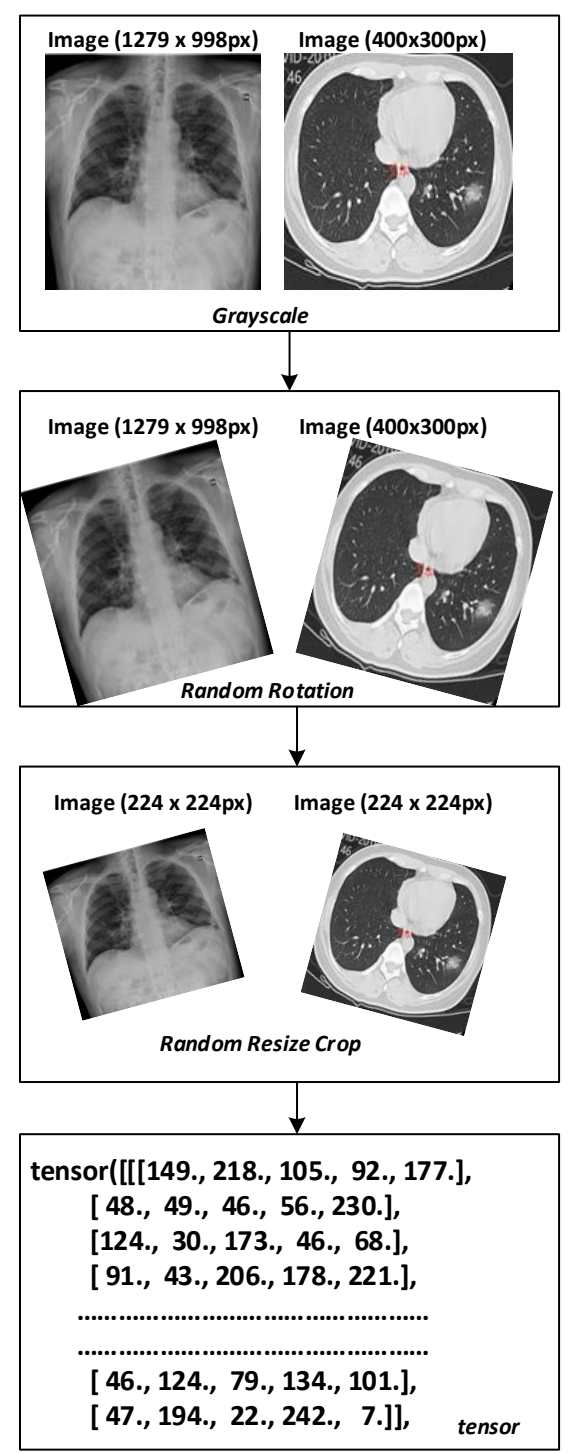

Gambar 2. Data Preprocessing

\section{Dataset Splitting}

Dataset splitting adalah membagi dataset citra X-Ray dan CT-Scan paruparu yang berjumlah 5074 citra digital ke dalam data training dan data testing dengan 3790 citra data training dan 1284 citra data testing.

\section{B. Arsitektur dan Config}

Pada tahap ini akan dilakukan pembuatan arsitektur model dan config. Arsitektur model CNN yang dibangun terdiri dari 5 lapisan convolutional layer, Relu layer, padding, dan max pooling pada feature learning. Sedangkan pada lapisan classification terdapat 1 lapisan flatten, dan
3 lapisan neural network atau fully connected dan pada lapisan softmax terdiri atas 3 output. Setelah arsitektur model CNN dibuat, maka tahap selanjutnya adalah config. Config berfungsi untuk mengatur semua parameter yang akan digunakan pada model yang akan dibangun. Beberapa hyperparameter yang akan digunakan untuk mendapatkan model dengan tingkat akurasi yang terbaik dalam model CNN tersebut dapat dilihat pada Tabel 1 .

Tabel 1. Config Hyperparameter Arsitektur CNN

\begin{tabular}{|c|l|}
\hline No & \multicolumn{1}{|c|}{ Hyperparameter } \\
\hline 1 & Input Citra \\
\hline 2 & Convolutional Layer \\
\hline 3 & Activation \\
\hline 4 & Pooling \\
\hline 5 & Kernel \\
\hline 6 & Padding \\
\hline 7 & Stride \\
\hline 8 & Optimizer \\
\hline 9 & Early Stopping \\
\hline 10 & Learning Rate \\
\hline 11 & Loss Function \\
\hline 12 & Flatten \\
\hline 13 & Fully Connected \\
\hline 14 & Output \\
\hline
\end{tabular}

\section{Training Preparation}

Sebelum ke tahap training, hal yang harus dilakukan adalah training preparation. Hal tersebut dilakukan untuk mempersiapkan hal yang harus di setting untuk keperluan training. Adapun hal yang harus di setting antara lain, yaitu memasukkan arsitekturnya atau model, mengatur criterion atau loss function yang akan digunakan, mengatur optimizer yang akan digunakan, dan mengatur callback atau jumlah epoch secara otomatis. Empat hal tersebut biasa disebut dengan MCOC (Model, Criterion, Optimizer, Callback).

\section{Training Model CNN}

Setelah melakukan data preprocessing, membuat arsitektur dan config, serta melakukan training preparation. Maka tahap selanjutnya adalah melakukan training model yang 
telah dirancang pada tahap sebelumnya. Tahap ini merupakan proses pelatihan terhadap data citra training $X$-Ray dan $C T$ Scan dalam mendeteksi atau mengklasifikasikan Covid-19 pada paruparu dengan algoritma Convolutional Neural Network atau CNN.

\section{E. Model Prediksi CNN}

Dari hasil pelatihan seluruh data citra X-Ray dan CT-Scan paru menggunakan CNN, maka didapatkan sebuah model prediksi yang selanjutnya akan diukur nilai keakuratannya dengan memasukkan data testing citra X-Ray dan CT-Scan paru ke dalam model tersebut.

\section{F. Evaluation}

Evaluation merupakan tahapan untuk mengevaluasi suatu model klasifikasi yang telah dibuat dengan meggunakan data testing. Adapun hal yang harus dilihat pada tahap ini antara lain :

\section{Akurasi}

Pada tahap ini dilakukan untuk mengukur kinerja dari model CNN yang telah dibuat dalam mengklasifikasi Covid-19 pada citra $X$-Ray dan CT-Scan paru.

\section{Visualisasi Performa Model}

Pada tahap ini dilakukan untuk mengukur kinerja dari model CNN yang telah dibuat dalam mengklasifikasi Covid-19 pada citra $X$-Ray dan CT-Scan paru dengan bentuk visualisasi atau grafik. Visualisasi tersebut antara lain confusion matrix dan ROC-AUC curve.

\section{HASIL DAN PEMBAHASAN}

\section{Skenario Model CNN}

Dalam penelitian ini, peneliti memulai eksperimennya dengan melakukan beberapa skenario terhadap arsitektur $\mathrm{CNN}$ yang dibuat. Skenario tersebut dibuat dengan tujuan untuk menemukan model terbaik dengan cara tunnning hyperparameter. Berikut adalah hyperparameter yang digunakan pada 3 skenario dapat dilihat pada Tabel 2.
Tabel 2. Hyperparameter Skenario Arsitektur CNN

\begin{tabular}{|c|c|c|c|}
\hline \multirow{2}{*}{$\begin{array}{c}\text { Hyper- } \\
\text { parameter }\end{array}$} & \multicolumn{3}{|c|}{ Skenario } \\
\hline & I & II & III \\
\hline Input Citra & \multicolumn{3}{|c|}{$1 \times 224 \times 224$} \\
\hline \multirow{6}{*}{ 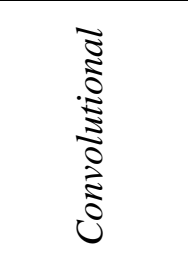 } & 8 & 8 & 8 \\
\hline & 16 & 16 & 16 \\
\hline & 32 & 32 & 32 \\
\hline & 64 & 64 & 64 \\
\hline & 128 & 128 & 128 \\
\hline & 256 & 256 & 256 \\
\hline Activation & \multicolumn{3}{|c|}{ ReLU } \\
\hline Pooling & $(2,2)$ & $(2,2)$ & $(2,2)$ \\
\hline Kernel & $(5,5)$ & $(3,3)$ & $(7,7)$ \\
\hline Padding & $(2,2)$ & $(1,1)$ & $(3,3)$ \\
\hline Stride & $(1,1)$ & $(1,1)$ & $(1,1)$ \\
\hline Optimizer & \multicolumn{3}{|c|}{ Adamw } \\
\hline $\begin{array}{c}\text { Early } \\
\text { Stopping }\end{array}$ & 10 & 10 & 10 \\
\hline $\begin{array}{l}\text { Learning } \\
\text { Rate }\end{array}$ & 0.001 & 0.001 & 0.001 \\
\hline $\begin{array}{c}\text { Loss } \\
\text { Function }\end{array}$ & \multicolumn{3}{|c|}{ NLLLOSS } \\
\hline Flatten & \multicolumn{3}{|c|}{$256 \times 7 \times 7$} \\
\hline \multirow{4}{*}{$\begin{array}{c}\text { Fully } \\
\text { Connected } \\
1\end{array}$} & $\begin{array}{l}12544, \\
512\end{array}$ & $\begin{array}{l}12544, \\
512\end{array}$ & $\begin{array}{c}1254, \\
512\end{array}$ \\
\hline & \multicolumn{3}{|c|}{ Batch Norm (False) } \\
\hline & \multicolumn{3}{|c|}{$\begin{array}{c}\text { Activation } \\
\text { (ReLU) }\end{array}$} \\
\hline & \multicolumn{3}{|c|}{ Dropout $(15 \%)$} \\
\hline \multirow{4}{*}{$\begin{array}{c}\text { Fully } \\
\text { Connected } \\
2\end{array}$} & $\begin{array}{l}512, \\
256\end{array}$ & $\begin{array}{l}512, \\
256\end{array}$ & $\begin{array}{l}512, \\
256\end{array}$ \\
\hline & \multicolumn{3}{|c|}{ Batch Norm (false) } \\
\hline & \multicolumn{3}{|c|}{$\begin{array}{l}\text { Activation } \\
\text { (ReLU) }\end{array}$} \\
\hline & \multicolumn{3}{|c|}{$\begin{array}{c}\text { Dropout } \\
(15 \%)\end{array}$} \\
\hline
\end{tabular}

\begin{tabular}{|c|c|c|c|}
\hline \multirow{2}{*}{$\begin{array}{c}\text { Fully } \\
\text { Connected } \\
3\end{array}$} & \multicolumn{3}{|c|}{$\begin{array}{c}\text { Activation } \\
\text { (LogSoftmax) }\end{array}$} \\
\cline { 2 - 4 } Output & 3 & 3 & 3 \\
\hline
\end{tabular}

\section{Evaluasi Skenario Model CNN}

\section{Akurasi dan Cost}

Berdasarkan pada skenario I, II dan III dengan rancangan arsitektur pada Tabel 2. Maka, hasil akurasi dan cost yang diperoleh dapat dilihat pada Gambar 3 dan Gambar 4. 

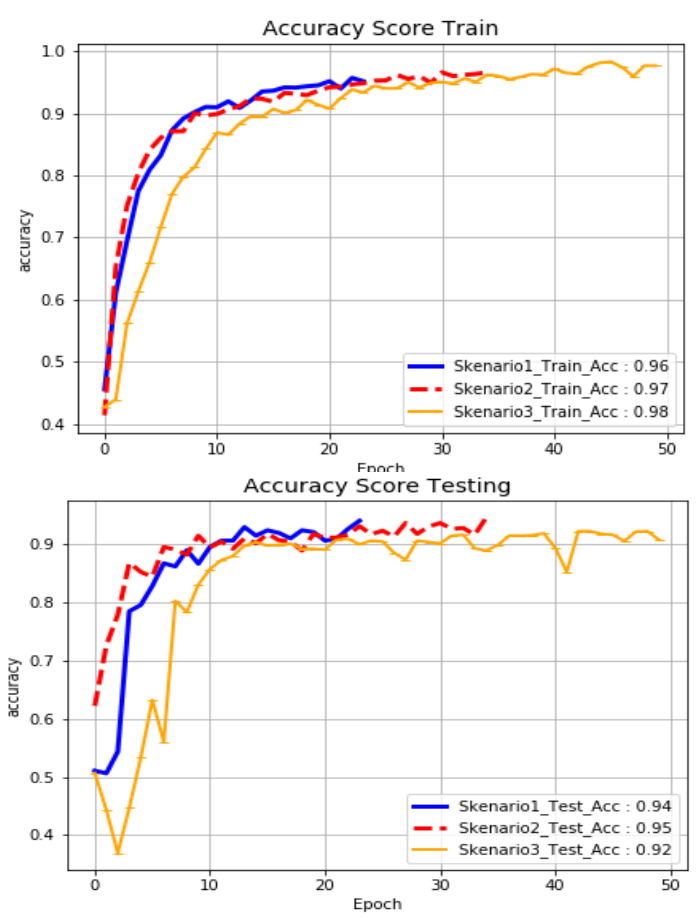

Gambar 3. Akurasi Model CNN Skenario I, II, dan III

Gambar 3 di atas dapat dideskripsikan bahwa ketika nilai cost pada data testing sudah mengalami penurunan sebanyak nilai early stopping yang diberikan, maka proses training model akan berhenti. Pada skenario I akan berhenti pada epoch ke-35, skenario II akan berhenti pada epoch ke45 , sedangkan pada skenario III akan berhenti pada epoch ke-53. Sehingga akurasi tertinggi atau model yang terbaik untuk skenario I berada pada epoch ke-23 dengan memperoleh hasil 0,96 untuk training dan 0,94 untuk testing. Akurasi tertinggi untuk skenario II berada pada epoch ke-34 dengan memperoleh hasil 0,97 untuk training dan 0,95 untuk testing. Sedangkan akurasi tertinggi untuk skenario III berada pada epoch ke-48 dengan memperoleh hasil 0,98 untuk training dan 0,92 untuk testing. Sedangkan untuk nilai cost pada skenario I, II dan III dapat dilihat pada Gambar 4.
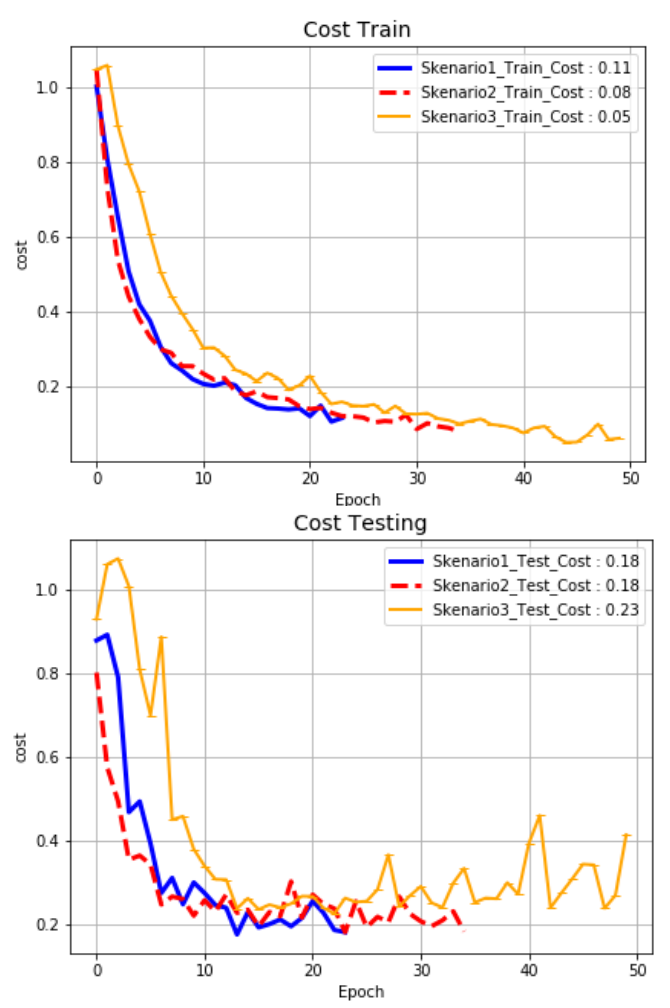

Gambar 4. Cost Model CNN Skenario I, II, dan III

Berdasarkan hasil pada Gambar 3 dan 4 di atas, dapat dideskripsikan bahwa pada kasus penelitian kali ini terhadap skenario yang dipilih, jumlah ukuran kernel yang dipakai pada arsitektur CNN yang dibangun mempengaruhi terhadap akurasi model pada saat testing, walaupun tidak terlalu signifikan. Hal ini dikarenakan jika menggunakan kernel dengan ukuran $3 \times 3$ pada skenario II, bahwa pengamatan dalam proses training model CNN akan menghasilkan lebih banyak informasi yang dihasilkan dari proses konvolusi, sehingga akan mempengaruhi terhadap akurasi yang dihasilkan akan sedikit lebih tinggi dari pada hasil pada skenario I dan III yaitu dengan akurasi sebesar $0,9477 \approx 0,95$.

\section{Confusion Matrix}

Hasil klasifikasi dalam mendeteksiCovid-19 pada data training dan testing citra CT-Scan dan X-Ray paru terhadap skenario I pada hasil epoch ke-23, dapat dilihat dengan lebih detail menggunakan tabel confusion matrix seperti pada Tabel 3. 
Tabel 3. Confusion Matrix Testing Skenario I

\begin{tabular}{|c|c|c|c|}
\hline Prediksi & 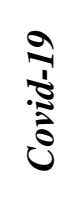 & 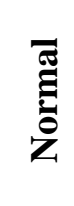 & 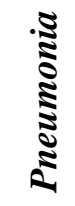 \\
\hline Covid-19 & 399 & 24 & 4 \\
\hline Normal & 13 & 405 & 13 \\
\hline Pneumonia & 1 & 14 & 411 \\
\hline
\end{tabular}

Tabel 3 di atas menunjukkan bahwa kolom diagonal merupakan kelas yang benar diprediksi oleh model, sedangkan untuk di luar kolom diagonal merupakan hasil kelas yang salah diprediksi oleh model.

Pada hasil confusion matrix data testing tersebut dapat dilihat bahwa 402 data kelas Covid-19 benar diprediksi oleh model, 24 kelas Covid-19 salah diprediksi terhadap kelas normal, dan 1 kelas Covid-19 salah diprediksi terhadap kelas Pneumonia. Sementara 399 data kelas normal benar diprediksi oleh model, 15 data kelas normal salah diprediksi terhadap kelas Covid-19, dan 17 data kelas normal salah diprediksi terhadap kelas Pneumonia. Sedangkan untuk kelas terakhir, 407 data kelas Pneumonia benar diprediksi oleh model, 13 data kelas Pneumonia salah diprediksi terhadap kelas Covid-19, dan 6 data kelas Pneumonia salah diprediksi terhadap kelas normal. Sehingga, jika dilihat dari banyaknya kelas yang benar diprediksi oleh model pada skenario I, didapatkan akurasi sebesar 0,94.

Pada skenario II, hasil yang didapat pada epoch ke-34 dapat dilihat dengan lebih detail menggunakan tabel confusion matrix seperti pada Tabel 4.

Tabel 4 di atas menunjukkan bahwa kolom diagonal merupakan kelas yang benar diprediksi oleh model, sedangkan untuk di luar kolom diagonal merupakan hasil kelas yang salah diprediksi oleh model.
Tabel 4. Confusion Matrix Testing Skenario II

\begin{tabular}{|c|c|c|c|}
\hline Prediksi & 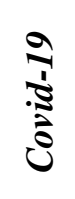 & 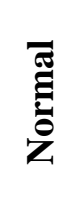 & 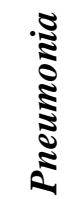 \\
\hline Covid-19 & 402 & 24 & 1 \\
\hline Normal & 15 & 399 & 17 \\
\hline Pneumonia & 13 & 6 & 407 \\
\hline
\end{tabular}

Pada hasil confusion matrix data testing tersebut dapat dilihat bahwa 399 data kelas Covid-19 benar diprediksi oleh model, 24 kelas Covid-19 salah diprediksi terhadap kelas normal, dan 4 kelas Covid-19 salah diprediksi terhadap kelas Pneumonia. Sementara 405 data kelas normal benar diprediksi oleh model, 13 data kelas normal salah diprediksi terhadap kelas Covid-19, dan 13 data kelas normal salah diprediksi terhadap kelas Pneumonia. Sedangkan untuk kelas terakhir, 411 data kelas Pneumonia benar diprediksi oleh model, 1 data kelas Pneumonia salah diprediksi terhadap kelas Covid-19, dan 14 data kelas Pneumonia salah diprediksi terhadap kelas normal. Sehingga, jika dilihat dari banyaknya kelas yang benar diprediksi oleh model pada skenario II, didapatkan akurasi sebesar 0,95.

Pada skenario III, hasil yang didapat pada epoch ke-48 dapat dilihat dengan lebih detail menggunakan tabel confusion matrix seperti pada Tabel 5.

Tabel 5. Confusion Matrix Testing Skenario III

\begin{tabular}{|c|c|c|c|}
\hline Prediksi & 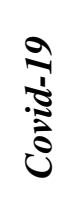 & 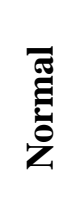 & 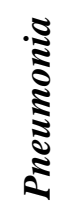 \\
\hline Covid-19 & 395 & 30 & 2 \\
\hline Normal & 35 & 381 & 15 \\
\hline Pneumonia & 2 & 15 & 409 \\
\hline
\end{tabular}

Tabel 5 di atas menunjukkan bahwa kolom diagonal merupakan kelas 
yang benar diprediksi oleh model, sedangkan untuk di luar kolom diagonal merupakan hasil kelas yang salah diprediksi oleh model.

Pada hasil confusion matrix data testing tersebut dapat dilihat bahwa 395 data kelas Covid-19 benar diprediksi oleh model, 30 kelas Covid-19 salah diprediksi terhadap kelas normal, dan 2 kelas Covid-19 salah diprediksi terhadap kelas Pneumonia. Sementara 381 data kelas normal benar diprediksi oleh model, 35 data kelas normal salah diprediksi terhadap kelas Covid-19, dan 15 data kelas normal salah diprediksi terhadap kelas Pneumonia. Sedangkan untuk kelas terakhir, 409 data kelas Pneumonia benar diprediksi oleh model, 2 data kelas Pneumonia salah diprediksi terhadap kelas Covid-19, dan 15 data kelas Pneumonia salah diprediksi terhadap kelas normal. Sehingga, jika dilihat dari banyaknya kelas yang benar diprediksi oleh model pada skenario III, didapatkan akurasi sebesar 0,92.

\section{Performa Hasil Skenario CNN}

Dalam mengevaluasi model CNN yang telah dilakukan pada skenario I, II, dan III dapat dilakukan dengan melihat performa model klasifikasi. Adapun ukuran evaluasi yang digunakan adalah precision, recall dan $f 1$-score. Gambar 5 menunjukkan hasil dari precision, recall dan $f 1$-score pada data testing skenario I, II dan III.

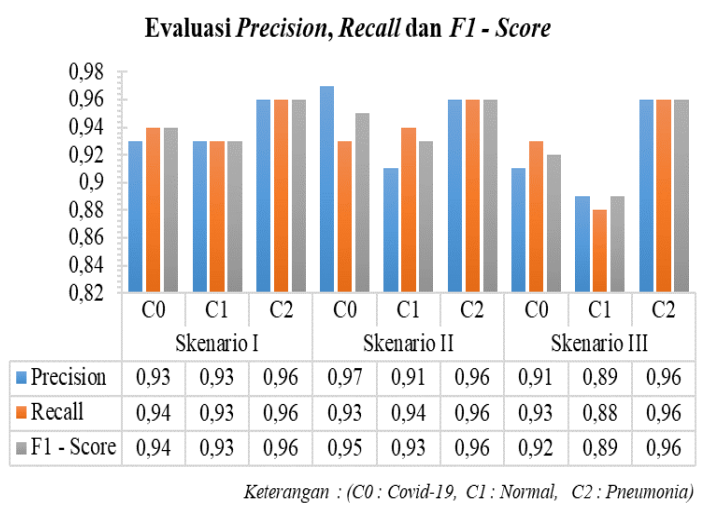

Gambar 5. Performa Hasil

Skenario I, II, dan III

$\begin{array}{rllll}\text { Gambar } & 5 & \text { di } & \text { atas } & \text { dapat } \\ \text { dideskripsikan } & \text { bahwa } & \text { hasil } & \text { pada }\end{array}$

skenario I menunjukkan precision pada kelas Covid-19 sebesar 0,93, nilai recall sebesar 0,94 , sehingga didapatkan nilai rata-rata atau fl-score sebesar 0,94. Sementara precision pada kelas normal sebesar 0,93, nilai recall sebesar 0,93, sehingga didapatkan nilai rata-rata atau fl-score sebesar 0,93. Sedangkan precision pada kelas Pneumonia sebesar 0,96 , nilai recall sebesar 0,96 , sehingga didapatkan nilai rata-rata atau fl-score sebesar 0,96 .

Pada skenario II menunjukkan precision pada kelas Covid-19 sebesar 0,97 , nilai recall sebesar 0,93 , sehingga didapatkan nilai rata-rata atau fl-score sebesar 0,95 . Sementara precision pada kelas normal sebesar 0,91 , nilai recall sebesar 0,94 , sehingga didapatkan nilai rata-rata atau fl-score sebesar 0,93. Sedangkan precision pada kelas Pneumonia sebesar 0,96, nilai recall sebesar 0,96, sehingga didapatkan nilai rata-rata atau $f 1$-score sebesar 0,96 .

Pada skenario III menunjukkan precision pada kelas Covid-19 sebesar 0,91 , nilai recall sebesar 0,93 , sehingga didapatkan nilai rata-rata atau fl-score sebesar 0,92. Sementara precision pada kelas normal sebesar 0,89 , nilai recall sebesar 0,88 , sehingga didapatkan nilai rata-rata atau fl-score sebesar 0,89 . Sedangkan precision pada kelas Pneumonia sebesar 0,96, nilai recall sebesar 0,96 , sehingga didapatkan nilai rata-rata atau $f 1$-score sebesar 0,96 .

Berdasarkan performa hasil pada skenario I, II, dan III di atas, dapat dilihat pada nilai fl-score yang dihasilkan ketiga skenario tersebut. Sehingga, model pada skenario II lebih baik dibandingkan dengan model pada skenario I dan III. Karena hasil pada model skenario II menunjukkan nilai rata-rata atau f1-score yang dihasilkan adalah yang tertinggi di ketiga kelasnya, yaitu Covid-19, normal, maupun kelas Pneumonia.

\section{Visualisasi Hasil Skenario CNN}

Selain confusion matrix, plot
kurva Receiver

Characteristic (ROC) dapat dilihat untuk mengevaluasi sebuah model 
prediksi yang dihasilkan pada setiap skenario dan akan menghasilkan kurva atau luas daerah prediksi untuk masingmasing kelas prediksi pada skenario I, II, dan III yang dapat dilihat pada Gambar 6, 7 dan 8 .
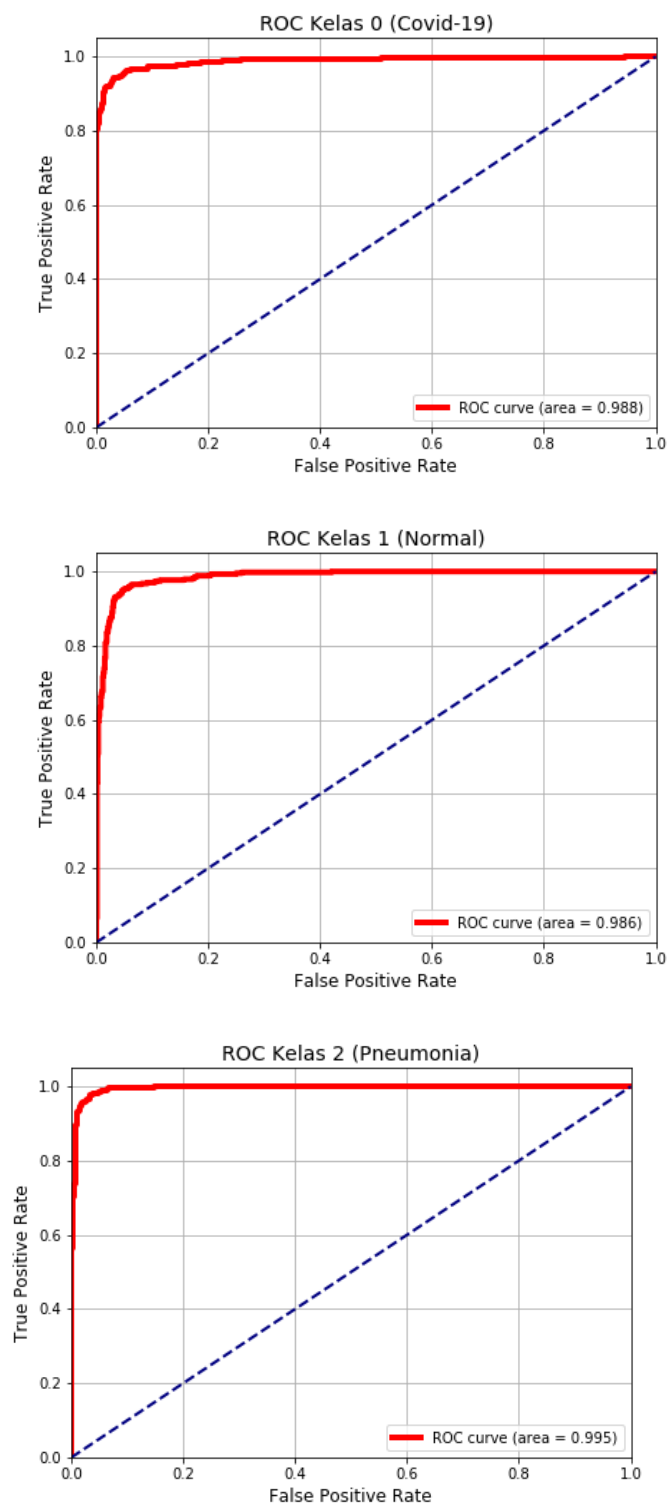

Gambar 6. Luas Daerah ROC Model CNN Skenario I

Gambar 6 di atas dapat dideskripsikan bahwa untuk mendapatkan luas daerah kurva ROC, maka dilakukan perbandingan nilai antara FPR (False Positive Rate) dan TPR (True Positive Rate) pada setiap kelas prediksi. Pada kelas Covid-19 memiliki luas daerah kurva sebesar 0,988 atau 98,8\%, kelas normal memiliki luas daerah kurva sebesar
0,986 atau 98,6\%, dan kelas Pneumonia memiliki luas daerah kurva sebesar 0,995 atau 99,5\%. Sedangkan luas daerah ROC pada skenario II dapat dilihat pada Gambar 7.
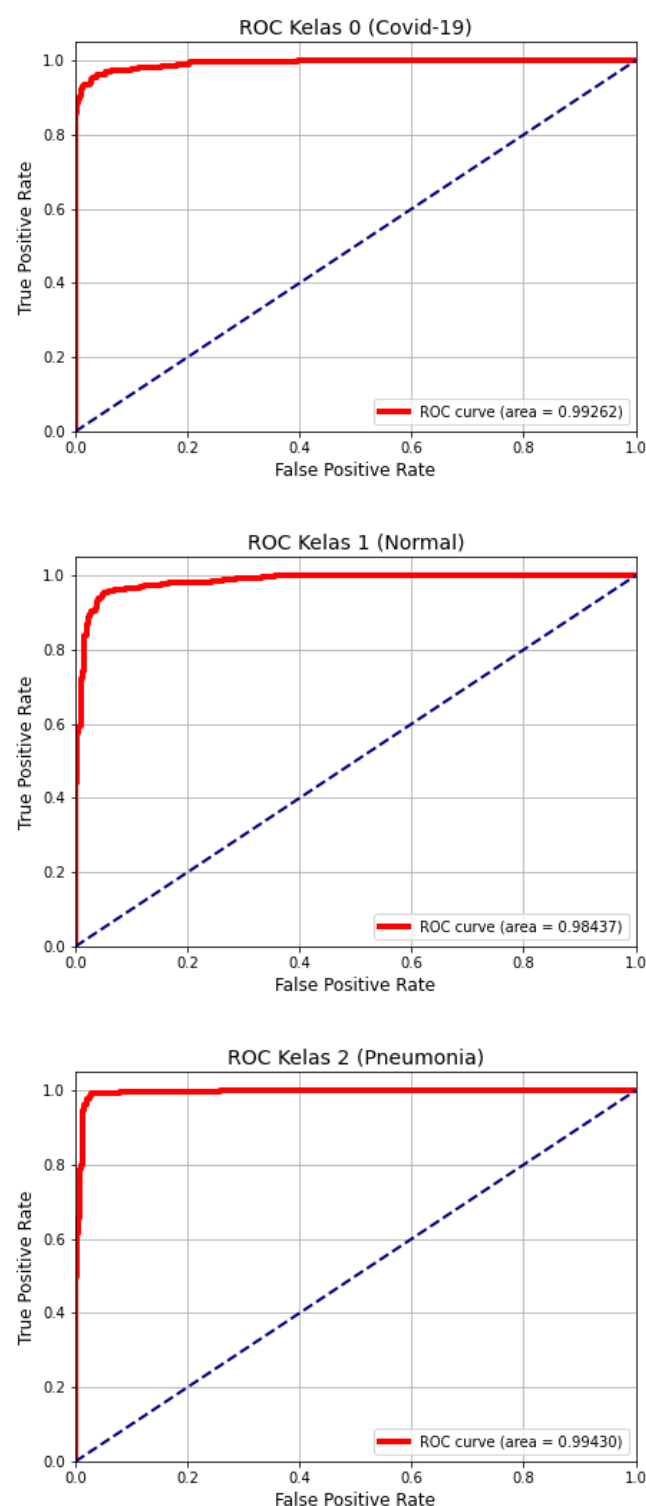

Gambar 7. Luas Daerah ROC Model CNN Skenario II

Gambar 7 di atas dapat dideskripsikan bahwa untuk mendapatkan luas daerah kurva ROC, maka dilakukan perbandingan nilai antara FPR (False Positive Rate) dan TPR (True Positive Rate) pada setiap kelas prediksi. Pada kelas Covid-19 memiliki luas daerah kurva sebesar 0,992 atau 99,2\%, kelas normal memiliki luas daerah kurva sebesar 0,984 atau 98,4\%, dan kelas Pneumonia 


\section{Vol.3 No.2, Desember 2020}

memiliki luas daerah kurva sebesar 0,994 atau 99,4\%. Sedangkan luas daerah ROC pada skenario III dapat dilihat pada Gambar 8.
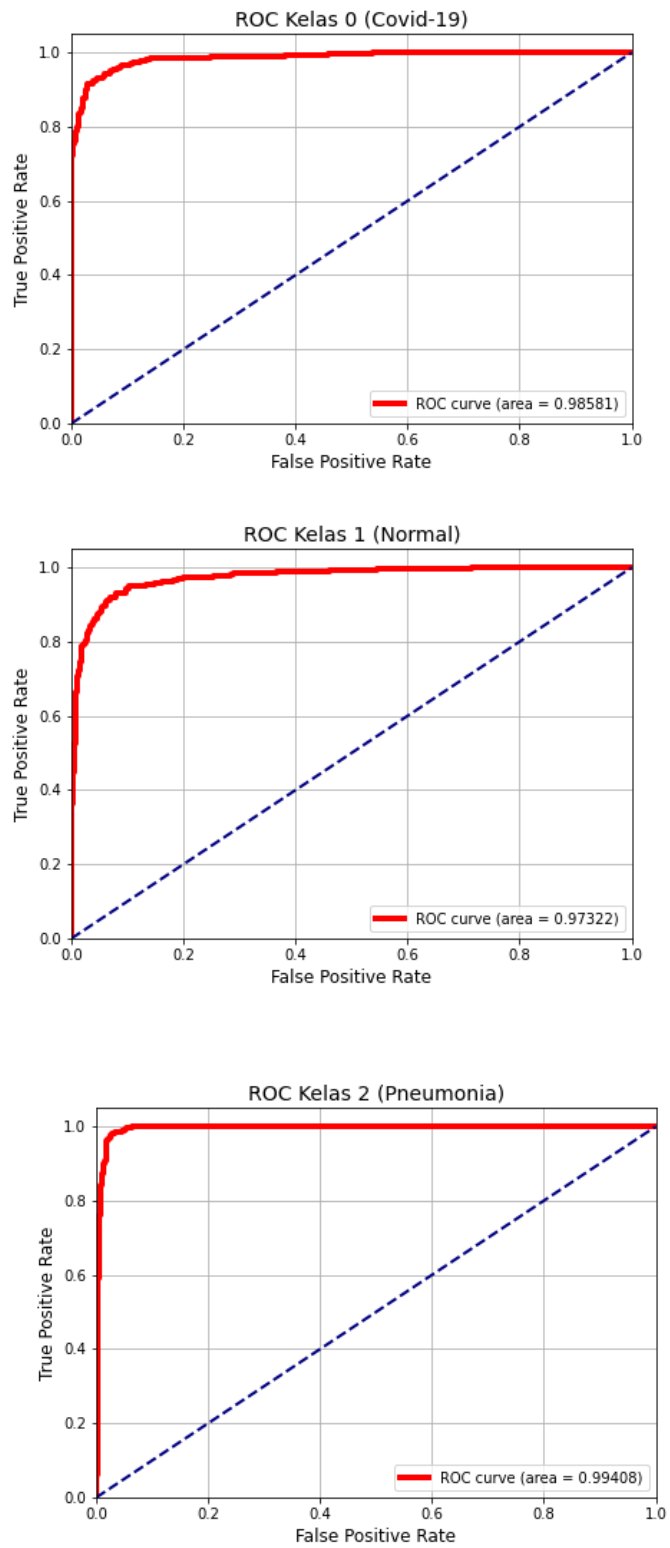

Gambar 8. Luas Daerah ROC Model CNN Skenario III

Gambar 8 di atas dapat dideskripsikan bahwa untuk mendapatkan luas daerah kurva ROC, maka dilakukan perbandingan nilai antara FPR (False Positive Rate) dan TPR (True Positive Rate) pada setiap kelas prediksi. Pada kelas Covid-19 memiliki luas daerah kurva sebesar 0,985 atau 98,5\%, kelas normal memiliki luas daerah kurva sebesar 0,973 atau 97,3\%, dan kelas Pneumonia memiliki luas daerah kurva sebesar 0,994 atau 99,4\%.

Berdasarkan hasil luas daerah kurva yang dihasilkan pada skenario I, II, dan III. Maka model pada skenario II lebih baik dibandingkan dengan model pada skenario I dan III. Karena hasil pada model skenario II menunjukkan nilai luas daerah kurva khususnya pada kelas Covid-19 lebih baik dibandingkan dengan skenario I dan III.

\section{KESIMPULAN}

Berdasarkan hasil pengujian dan analisis, penerapan algoritma $\mathrm{CNN}$ dalam mendeteksi Covid-19 pada citra X-Ray dan CT-Scan paru dapat diambil kesimpulan bahwa ukuran kernel yang digunakan pada setiap skenario dapat mempengaruhi terhadap akurasi yang dihasilkan. Dapat dilihat ketika menggunakan ukuran kernel $5 \times 5$ pada skenario I menghasilkan akurasi sebesar 94\%, ukuran kernel 3x3 pada skenario II menghasilkan akurasi sebesar $95 \%$ dan ukuran kernel $7 \mathrm{x} 7$ pada skenario III menghasilkan akurasi sebesar 93\%. Maka, pada kasus penelitian ini skenario II dengan ukuran kernel 3x3 menghasilkan akurasi lebih baik dibandingkan dengan dua ukuran kernel lainnya. Selain itu, performa model pada skenario II menghasilkan nilai precision, recall, $f 1$-score dan luas daerah kurva ROC-AUC lebih baik diantara skenario I dan III khususnya pada kelas Covid-19.

\section{REFERENSI}

al, C. T. (n.d.). Opportunities and Obstacles for Deep Learning in Biology and Medicine. J. R. Soc. Interface, 15: 20170387.

DOI: 10.1098/rsif.2017.0387.

Ali Narin, C. K. (2020). Automatic Detection of Coronavirus Disease (COVID-19) Using X-ray Images and Deep Convolutional Neural Networks. Turkey: Zonguldak Bulent Ecevit University.

Asmaa Abbas, M. M. (2020). Classification of COVID-19 in chest X-ray images using DeTraC deep convolutional neural network. 1-9.

Aswindo Putra, J. F. (2018). Paralelisasi Klasifikasi Data Ekspresi Gen Kanker 
Vol.3 No.2, Desember 2020

dengan Algoritma Deep Neural. eProceeding of Engineering, 8296.

Dean, J. (2014). Big Data, Data Mining, and Machine Learning. Canada: John Wiley \& Sons, Inc., Hoboken, New Jersey, simultaneously in Canada.

Diederik P. Kingma, J. L. (2015). ADAM: A Method For Stochastic Optimization. Amsterdam: conference paper at ICLR 2015.

dr. Fathiyah Isbaniah, S. F. (2020). Pedoman Kesiapsiagaan Menghadapi Coronavirus Disesase (Covid-19). Jakarta, Indonesia: Kementerian Kesehatan RI.

Gozes, O. F.-A. (2020). E. Rapid AI Development Cycle for the Coronavirus (COVID-19) Pandemic: nitial Results for Automated Detection \& Patient Monitoring using Deep Learning CT Image Analysis.

Ian Goodfellow, Y. B. (2015). Deep Learning. MIT Press, 2016.

Kemenkes. (2020, Juli 18). Kementerian Kesehatan. Retrieved from https://www.kemkes.go.id/ (diakses pada tanggal 18 Juli 2020)

Primartha, R. (2018). Belajar Machine Learning Teori dan Praktik. Bandung: Informatika Bandung.

Shan, F. G. (2020). Lung Infection Quantification of COVID-19 in CT Images with Deep Learning. arXiv preprint arXiv:2003.04655, 1-19.

Subramanian, V. (2018). Deep Learning with PyTorch · BIRMINGHAM

MUMBAI: Packt Publishing Ltd.

Sun T, Z. B. (2017). Sequence-Based Prediction of Protein protein Interaction. BMC Bioinformatics, Open Access"., 18:277.doi.org/10.1186/s12859-0171700-2.

Wang, S. K. (2020). A deep learning algorithm using CT images to screen for Corona Virus Disease (COVID-19). medRxiv preprint doi: https://doi.org/10.1101/2020.02.14.20 023028, 1-26.

WHO. (2020, Juli 18). World Health Organization. Retrieved from WHO Coronavirus Disease (COVID-19): https://covid19. who.int/?gclid=CjwK CAjw_qb3BRAVEiwAvwq6ViGpwp
uWaLMuxHFR6XwFB80nuUSsgt9hy VShCMn5IctjkCMT7hxL3BoCZIIQA vD_BwE (diakses pada tanggal $18 \mathrm{Juli}$ 2020)

Widodo Budiharto, D. S. (2014). Artificial Intelligence Konsep dan Penerapannya. Yogyakarta: CV Andi Offset.

WiraDKP. (2020). Retrieved from https://github.com/WiraDKP (diakses pada tanggal 15 Juni 2020)

$\mathrm{Xu}$, X. J. (2020). Deep Learning System to Screen Coronavirus Disease 2019 Pneumonia. arXiv preprint arXiv:2002.09334, 1-29.

Yuliana. (2020). Corona Virus Diseases (Covid-19). Wellness and Health Magazine, 187-192. 